\title{
Forecasts and Agromet Advisory Evaluation
}

\author{
H.S. Shivaramu* , H.S. Padmashri, K.K. Singh, L. Nagesha, M.H. Manjunatha, \\ H.T. Jayasshree and C.M. Munirathna
}

\author{
AICRP on Agrometeorology, UAS, GKVK, Bengaluru-560065, Karnataka, India \\ *Corresponding author
}

\begin{abstract}
A B S T R A C T
Key words

Weather forecast, Reliability, Trend, B: C ratio, Partial budgeting and cloud cover

Article Info

Accepted:

23 March 2018

Available Online:

10 April 2018

Regulating the erratic weather on a large scale is beyond human control. It is possible to adapt to or mitigate the ill effects of weather through appropriate Agromet advisories (AAS). The AAS are issued twice in a week, along with weather forecast for next 5 days covering the entire Eastern Dry Zone of Karnataka. Usability calculated for forecasts issued on rainfall, temperature and cloud cover from 2011 to 2016, ranged from 51 to 77 percent. Except for rainfall forecasts, usability of all other parameters is increasing over time. Among 616 AAS issued, 379 AAS recorded direct economic benefit by saving Rs. 37 lakhs. B: C ratio calculated for 5 years recorded were 2.62, 2.61, 2.59 and 2.22 for vegetables, fruits, flowers and field crops respectively. Timely advisories helped the grapes farmers of Patrenahalli and Nayanahalli village, Chikkaballapur district to decide timely irrigation, pruning, weeding, spraying and harvesting etc. These timely practices reduced the labour wages, pesticides costs and also lead to achieve better yield with overall benefits from grape growers alone was Rs.2.41Crores. Double cropping of field beanhorsegram gave benefit of 17.25 lakhs in project area of Kuthanagere micro-watershed even during drought year (2016) with deficit rainfall (-26.2\%).
\end{abstract}

\section{Introduction}

The agriculture strategies in post independent India has been characterized by injudicious use of resources like irrigation, biopesticides, fungicides and fertilizers in production and protection of crops and also diminution of natural vegetation, ground water and top soil surface runoff, and natural flora all are controlled by weather.

It can be seen that our present position of crop production has risen due to neglect of the effect of climate on several aspects of crop culture. By the same time agro met advisories have important roles to play in avoiding past mistakes and in ensuring future agricultural sustainability.

It is the fact that weather cannot be altered, except on limited scale but agricultural operations can be advanced or delayed with the help of advance weather forecasts from three to ten days.

Gramin Krishi Mausam Sewa (GKMS) project funded by India Meteorological Department (IMD), New Delhi, is operating in University 
of Agricultural Sciences, Bengaluru since 1996 utilizing the forecasts issued by India Meteorological department, Bengaluru. The unit has been serving the farmers' of this region by issuing the AAS to meet the changing needs of rainfed agriculture. The utility of weather forecast depends upon their reliability and applicability at micro level. The emerging ability to provide timely, skillful weather forecasts offers the potential to reduce human vulnerability to weather vagaries (Hansen, 2002).

Having said this, in this paper we have made an attempt to assess the reliability of forecasts issued by IMD and evaluate the cost economics of implementation of agromet advisory.

\section{Materials and Methods}

The Karnataka state is located between $11.5^{\circ}$ $\mathrm{N}$ and $18.5^{\circ} \mathrm{N}$ latitudes and between $74^{\circ} \mathrm{E}$ and $78.5^{\circ} \mathrm{E}$ longitude. The elevation varies between $600 \mathrm{~m}$ to $900 \mathrm{~m}$ above mean sea level (Rajegowda, 1999). The state comprises of ten Agro Climatic Zones. The geographical location of the study area lies in the Eastern Dry Zone (EDZ) of Karnataka with altitude ranging from 800 to $900 \mathrm{~m}$ above mean sea level with annual rainfall ranging from 679 $\mathrm{mm}$ to $889 \mathrm{~mm}$. It represents 9.1 per cent of the total cropped area of the State (Karnataka at glance 2002-03).

\section{Reliability of forecasts}

To assess the reliability of weather forecasts, error structure (Table 1) has been calculated for rainfall, temperature and cloud cover, issued from 2011 to 2016 (GKMS, 2011 to 2016). The correct and usable cases summed up and the combined values indicate the percent usability of the forecasts (Singh et al., 1999). Trend line is also fit for the usability per cent.

\section{Results and Discussion}

Integrated Agromet Advisory and Forecast Dispersion

Every Tuesday and Friday Agromet advisories are dispersed both in English and regional language (Kannada) to Bengaluru (Urban), Bengaluru (Rural), Chikkaballapur, Kolar and Ramanagara at district level. As an experiment we started dispersing advisory to 3 villages (Nayanahalli, Patrenahalli and Myalapanahalli) of Chikkaballapur district and Kuthanagere watershed area of Magadi Taluk, Ramanagara district from 2011.

\section{Evaluation of implementation of Agro met Advisories (AAS)}

An agriculturally relevant forecast is not only useful for efficient management of farm inputs but also leads to precise impact assessment (Gadgil, 1989). Evaluation of implementation of Agro met Advisories by the farmers, regular estimation of benefit/loss on each item of the advisory realized at the farmers level, economic benefit/loss on adoption of the agro advisory issued by the Agro met division compared with the non-AAS farmers. For this purpose, about 80 farmers from four villages near the nodal centre have been identified to know the economic benefit obtained by the farmers adopting the Agromet advisories. Weather forecast and Agro advisories were provided to AAS farmers during Kharif and Rabi season and no information was provided to Non AAS farmers.

A field survey of the study area was conducted and feedback from twenty farmers from each village were chosen and the feedback collected and summarized by recording the yield of the crops from two situations viz., recommended practices with agro-advisory and recommended practices without agro advisory. 


\section{Usability of forecasts}

The overall mean usability (Table 2 ) indicates that the rainfall usability varied 39.4 to 76.6 percent over the years. The annual usability of temperature ranged from 63.4 to 89.4 per cent while for cloud cover it was from 43.6 to 72.8 per cent. An estimate made by agribusiness a community in western countries indicates that the forecast can be put to an economical use if it is 50-60 per cent realized (Seeley, 1994). Trend lines presented in Table 2 shows that except for rainfall forecasts, reliability of all other weather parameters viz. maximum, minimum temperature and cloud cover is increasing (Fig. 1) over the years. Temperature and cloud cover trend lines have higher $\mathrm{R}^{2}$ values indicating positive

\section{Success of AAS issued}

Every Tuesday and Friday Agromet advisories are dispersed both in English and regional language (Kannada) to Bengaluru (Urban), Bengaluru (Rural), Chikkaballapur, Kolar and Ramanagara at district level. An average of around 62 per cent of the advisories dispersed advisory to 3 villages (Nayanahalli, Patrenahalli and Myalapanahalli) of Chikkaballapur district and Kuthanagere watershed area of Magadi Taluk, Ramanagara district from 2011. Among the 616 AAS issued, 379 AAS had recorded direct economic benefit by saving Rs. 37 lakhs to the 550 farmers from 2011 to 2016 (NICRA, 2011 to 2016). Thus, on an average Rs.6808 was saved by each farmer (Table 3 ).

\section{Benefit: Cost ratio of AAS and non-AAS farmers}

Among the different crops of adapted villages, vegetable crops recorded higher $\mathrm{B}: \mathrm{C}$ ratio (2.62) followed by fruit crops (2.61), flower crops (2.59) and field crops (2.2) against 'Non-AAS farmers' i.e. fruit crops (1.72), vegetable crops (1.61), field crops (1.57) and flower crops (1.42) respectively (Table 4 and $5)$.

\section{Partial budgeting of climate resilient practices- Success stories}

Success story-1: Productivity enhancement in grapes due to agromet advisories in Chikkaballapur

Water table of Chikkaballapur - Kolar belt of grapes is highly affected beyond rejuvenation. To address this problem, meticulously worked out Agromet advisories (AAS) based on weather forecast twice a week is dispersed to the farmers of Patrenahalli and Nayanahalli villages of Chikkaballapur taluk. Partial budgeting of grapes cultivation through AAS has been done for two years (NICRA, 2015 and 2016) (Table 6).

\section{Area covered}

Nearly 200 farmers were monitored under the project out of which 150 were grape growers in an area of 90 hectares.

\section{More crop per drop}

All the grape growers were advised for drip irrigation through synergy from state horticultural department, watershed department and KVK etc. The farmers were given subsidy for drip irrigation through line department and advisories were given from NICRA (National Innovations Climate Resilient Agriculture) project with respect to schedule of irrigation based on rainfall forecast. This resulted in the best water use efficiency besides the quality of produce.

Among the advisories given, timely pruning was the best advice given based on the rainfall forecast and most of the AAS farmers followed this advice, thus resulted in higher 
yield, quality bunches and premier market rates due to appealing color and less disease infestation.

\section{No pests, diseases and birds attack}

Weather forecast helped in forecasting pests and diseases. Low relative humidity $(\mathrm{RH}<80)$ is highly favorable to powdery mildew disease and high RH (>90) and intermittent rains with less temperature $\left(17-25^{\circ} \mathrm{C}\right)$ is favorable to downy mildew. These two diseases are problematic and cause significant yield loss in grapes. These two diseases are effectively managed through advisories. Grape farmers were also advised to use the nylon mesh around the grape plantation to restrict the entry of birds so that damage and yield loss could be minimized effectively.

Table.1 Error table

\begin{tabular}{|c|c|c|c|}
\hline Parameter & Correct & Usable & Unusable \\
\hline $\begin{array}{l}\text { Actual Rainfall } \\
\leq 10 \mathrm{~mm}\end{array}$ & Diff $\leq 2.5 \mathrm{~mm}$ & $2.5 \mathrm{~mm}<\operatorname{Diff} \leq 5 \mathrm{~mm}$ & Diff $>5 \mathrm{~mm}$ \\
\hline $\begin{array}{l}\text { Actual Rainfall } \\
>10 \mathrm{~mm}\end{array}$ & $\begin{array}{c}\text { Diff } \leq 25 \% \text { of } \\
\text { observation }\end{array}$ & $\begin{array}{c}25 \%<\text { Diff } \leq 50 \% \text { of } \\
\text { observation }\end{array}$ & Diff $>50 \%$ of observation \\
\hline Temperature & $\pm 1^{\circ} \mathrm{C}$ & $\pm 2^{\circ} \mathrm{C}$ & $>2{ }^{\circ} \mathrm{C}$ \\
\hline Cloud cover & \pm 1 Oktas & \pm 2 Oktas & $>3$ Oktas \\
\hline
\end{tabular}

Table.2 Average usability (\%) of rainfall, temperature and cloud cover

\begin{tabular}{|c|c|c|c|c|}
\hline Year & Rainfall & Max. Temp & Min. Temp & Cloud cover \\
\hline $\mathbf{2 0 1 1}$ & 76.6 & 64.0 & 63.4 & 43.6 \\
\hline $\mathbf{2 0 1 2}$ & 39.4 & 73.4 & 75.4 & 59.4 \\
\hline $\mathbf{2 0 1 3}$ & 42.8 & 78.4 & 66.2 & 63.8 \\
\hline $\mathbf{2 0 1 4}$ & 50.2 & 81.6 & 67.0 & 66.0 \\
\hline $\mathbf{2 0 1 5}$ & 49.0 & 74.4 & 71.2 & 72.8 \\
\hline $\mathbf{2 0 1 6}$ & 46.4 & 89.4 & 87.8 & 67.8 \\
\hline Average & $\mathbf{5 0 . 7}$ & $\mathbf{7 6 . 9}$ & $\mathbf{7 1 . 8}$ & $\mathbf{6 2 . 2}$ \\
\hline Trend & $\mathbf{y}=\mathbf{- 3 . 2 8 x}+\mathbf{6 2 . 2 1}$ & $\mathbf{y = 3 . 8 0 5 x + \mathbf { 6 3 . 5 4 }}$ & $\mathbf{y = 3 . 1 4 8 x + \mathbf { 6 0 . 8 1 }}$ & $\mathbf{y}=\mathbf{4 . 6 6 8 x}+\mathbf{4 5 . 8 9}$ \\
\hline line & & $\mathbf{0 . 6 9 3}$ & $\mathbf{0 . 4 4}$ & $\mathbf{0 . 7 4 1}$ \\
\hline $\mathbf{R}^{\mathbf{2}}$ & $\mathbf{0 . 2 1 3}$ & $\mathbf{0 . 4 5}$ & \\
\hline
\end{tabular}

Table.3 Success of AAS issued and amount saved per AAS farmer over 5 years (2011-16)

\begin{tabular}{|c|c|c|c|c|c|c|}
\hline Year & $\begin{array}{c}\text { AAS } \\
\text { issued }\end{array}$ & Successful AAS & Percent & $\begin{array}{c}\text { Amount } \\
\text { Saved (Rs) }\end{array}$ & $\begin{array}{c}\text { No. of } \\
\text { Farmers }\end{array}$ & $\begin{array}{c}\text { Amount saved(Rs.) } \\
\text { / farmer }\end{array}$ \\
\hline 2011 & 104 & 61 & 58.7 & 90,599 & 60 & 1,510 \\
\hline 2012 & 103 & 68 & 66.0 & $1,60,320$ & 158 & 1,015 \\
\hline 2013 & 101 & 72 & 71.3 & $9,06,203$ & 125 & 7,250 \\
\hline 2014 & 103 & 59 & 57.3 & $7,98,550$ & 84 & 9,507 \\
\hline 2015 & 104 & 56 & 53.8 & $13,47,885$ & 57 & 23,647 \\
\hline Total & 101 & 63 & 62.3 & $4,41,015$ & 66 & 6,682 \\
\hline
\end{tabular}

Note: * indicates average values 
Table.4 Benefit B:C ratio of AAS and non-AAS farmers' over 5 years (2011-2016)

\begin{tabular}{|l|}
\hline Name of the crop \\
\hline Field crops \\
\hline Vegetable crops \\
\hline Flower crops \\
\hline Fruit crops \\
\hline
\end{tabular}

\begin{tabular}{|c|c|}
\hline \multicolumn{2}{|c|}{ B:C ratio } \\
\hline AAS Farmers(48) & NON-AAS Farmers(48) \\
\hline 2.59 & 1.57 \\
\hline 2.62 & 1.61 \\
\hline 2.20 & 1.42 \\
\hline 2.61 & 1.72 \\
\hline
\end{tabular}

Table.5 Impact of weather based agro advisories in grapes during 2015-16 and 2016-17 (average of two years, $n=10$ )

\begin{tabular}{|l|l|l|l|l|l|l|l|} 
Groups of farmers & $\begin{array}{c}\text { Producti } \\
\text { vity } \\
\text { (t/ha) }\end{array}$ & $\begin{array}{c}\text { cost of } \\
\text { production } \\
\text { Rs/ha }\end{array}$ & $\begin{array}{l}\text { Gross } \\
\text { income } \\
\text { Rs/ha }\end{array}$ & $\begin{array}{l}\text { \% } \\
\text { increase } \\
\text { in } \\
\text { income }\end{array}$ & $\begin{array}{l}\text { Reduced } \\
\text { cost } \\
\text { (Rs/ha) }\end{array}$ & $\begin{array}{l}\text { Additio } \\
\text { nal } \\
\text { return } \\
\text { (Rs/ha) }\end{array}$ & B:C ratio \\
\hline Non AAS farmers & 28.50 & $1,15,000$ & 6.27000 & - & - & - & 5.45 \\
\hline AAS farmers & 35.00 & 95,000 & $8,75,000$ & 149 & $-20,000$ & $2,68,000$ & 9.21 \\
\hline
\end{tabular}

Note: Market Rate of grapes ranged from Rs. 22,000 to Rs. 40,000 per ton.

Table.6 Productivity enhancement through climate resilient system of field bean- horse gram double cropping system against single cropping of finger millet during 2016 drought year $(n=10)$

\begin{tabular}{|c|c|c|c|c|c|c|}
\hline $\begin{array}{l}\text { Cropping } \\
\text { system }\end{array}$ & Productivity (q/ha) & $\begin{array}{l}\text { Income } \\
\text { (Rs/ha) }\end{array}$ & $\begin{array}{c}\% \\
\text { increase } \\
\text { in } \\
\text { income }\end{array}$ & $\begin{array}{l}\text { Addition } \\
\text { al cost } \\
\text { (Rs/ha) }\end{array}$ & $\begin{array}{l}\text { Addition } \\
\text { al return } \\
\text { (Rs/ha) }\end{array}$ & $\begin{array}{l}\text { Additional } \\
\text { return to the } \\
\text { additional } \\
\text { cost }\end{array}$ \\
\hline $\begin{array}{c}\text { Finger } \\
\text { millet }\end{array}$ & $\begin{array}{c}\text { Grain } 7.00 \\
\text { Straw } 12.00\end{array}$ & 35,500 & - & - & - & \\
\hline $\begin{array}{c}\text { Field bean- } \\
\text { finger } \\
\text { millet } \\
\text { double } \\
\text { cropping } \\
\text { system }\end{array}$ & $\begin{array}{c}\text { Field bean harvested } \\
\text { for vegetable } 20.30 \\
\text { Finger millet grain } 0.00 \\
\text { Finger millet Straw } \\
2.30\end{array}$ & 84,650 & 138 & 31500 & 53,150 & 1.69 \\
\hline $\begin{array}{l}\text { Field bean- } \\
\text { horsegram } \\
\text { + niger } \\
\text { double } \\
\text { cropping } \\
\text { system }\end{array}$ & $\begin{array}{c}\text { Field bean harvested } \\
\text { for vegetable } 20.30 \\
\text { Horse gram } 3.00 \\
\text { Niger } 1.10\end{array}$ & $\begin{array}{c}1,00,50 \\
0\end{array}$ & 280 & 33000 & 67,500 & 2.04 \\
\hline
\end{tabular}

Note: Market rates used for calculation - Vegetable field bean Rs.4,000/q, finger millet grain= Rs.2,500/q, finger millet straw $=$ Rs. $1,500 / \mathrm{q}$, horse gram $=$ Rs.3,500/q, niger $=$ Rs. $8000 / \mathrm{q}$,

$*$ Input cost $=$ finger millet $=$ Rs 35/kg, horsegram= Rs 60/kg, field bean $=$ Rs $140 / \mathrm{kg}$, niger $=$ Rs $100 / \mathrm{kg}$

** Farmers who have harvested field bean for seeds instead of vegetable pods got 5.1 quintal per ha (the rate of field bean seeds $=$ Rs. $8,000 / q)$ 
Table.7 Partial budgeting to assess the benefits of climate resilient system of field bean-horse gram + niger double cropping against single cropping of finger millet during 2016 drought year $(n=10)$

\begin{tabular}{|r|l|l|} 
SI no & \multicolumn{1}{|c|}{ Debit column (Rs./ha) } & \multicolumn{1}{c|}{ Credit Column (Rs./ha) } \\
\hline 1 & $\begin{array}{l}\text { Additional cost for seeds, } \\
\text { labour and pesticidesRs.33,000 }\end{array}$ & Reduced cost Rs0 \\
\hline 2 & $\begin{array}{l}\text { Reduced return Rs 0 } \\
\text { Tdditional returns from vegetable }\end{array}$ & $\begin{array}{l}\text { Add } \\
\text { field bean, niger and horse gram Rs } 67,500\end{array}$ \\
\hline 3 & Total additional cost Rs33,000 & Total additional gain Rs67,500 \\
\hline 4 & Net gain = Rs.67,500 - Rs.33,000 = Rs.34,500/ha
\end{tabular}

Fig.1 Usability of forecasts

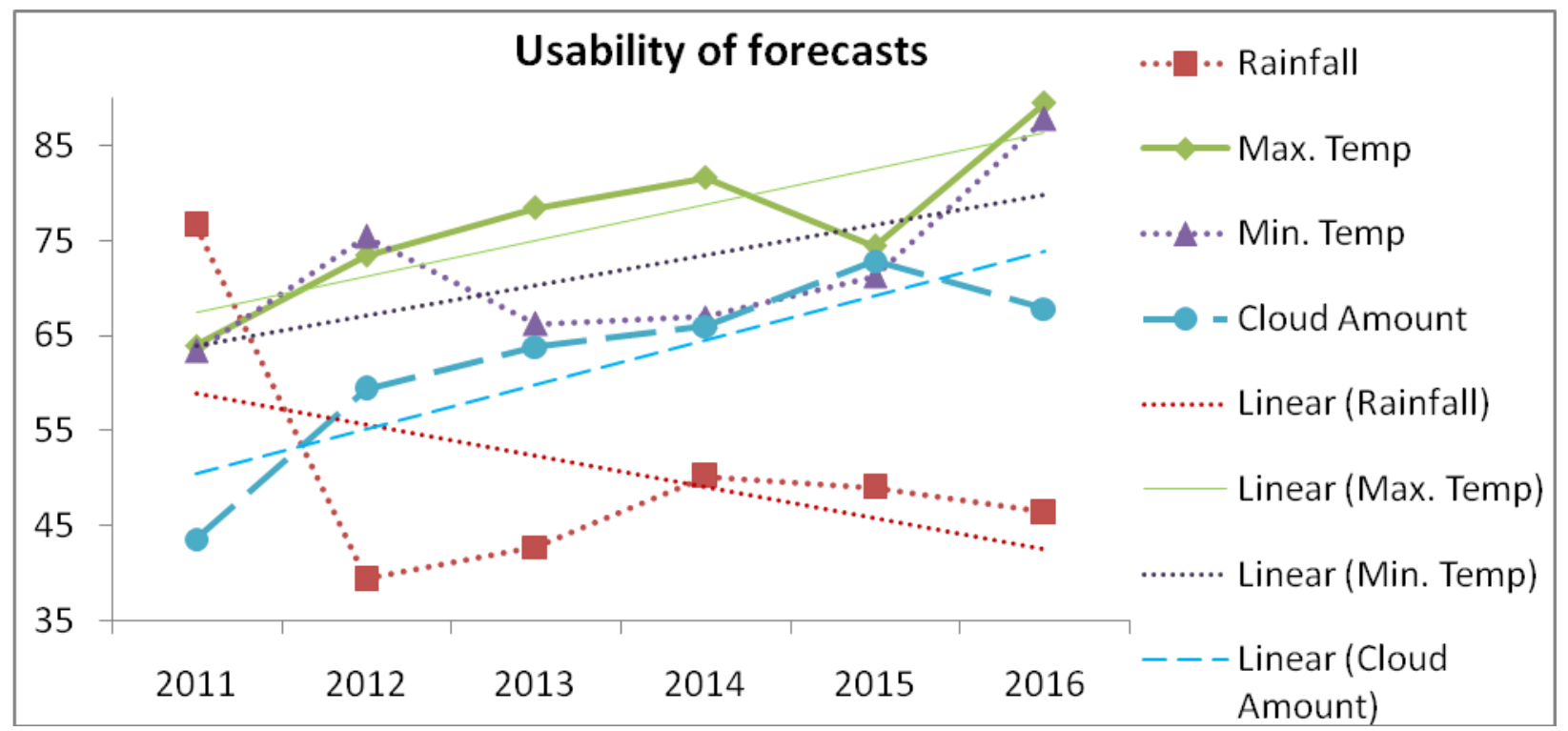

\section{Higher income}

Timely advisories helped the farmers to decide timely cultivation practices viz., irrigation, pruning, weeding, spraying and harvesting etc. These timely practices reduced the labour wages, pesticides costs and also lead to achieve better yield by the farmers.

Partial budgeting to assess the impact of agromet advisories in grapes revealed that the total net gain was Rs.2,68,000 per ha including the total additional return (Rs. 2,48,000/ha) and reduced cost (Rs. 20,000/ha) due to savings in irrigation, pesticides spray and timely pruning due to agromet advisories from sample survey of AAS farmers. Overall benefits from the project due to Agromet advisories from grape growers alone was Rs.2.41Crores, including the synergy from line departments, KVKs, Agricultural Research Stations and NGOs in the district

\section{Success story-2: field bean- horse gram double cropping system}

Ramanagara is one of the south interior districts of Karnataka famous for finger millet, field bean, Redgram, ground nut and mango. Besides these, mulberry cultivation 
for silk rearing was an age old livelihood enterprise dwindling in the recent years. Due to the intervention by the University of Agricultural Sciences, Bengaluru under watershed development programme, mango based Agri-horti system was recommended and now has become a very popular practice throughout the district. Therefore, instead of only finger millet mono cropping, field beanfinger millet double cropping or field beanhorse gram double cropping systems were advised to the farmers under NICRA project in operation at Kuthanagere micro watershed (NICRA, 2016). Farmers' were informed of the weather condition prevailing in the next five days besides long range weather forecast and extreme weather events during the cropping season through block level agromet advisories twice a week.

\section{Area covered}

Nearly 100 farmers were monitored under the project out of which 40 had adopted the double cropping systems based on our advice instead of mono cropping of finger millet only. The total area covered under double cropping systems of field bean-horse gram was around 50 hectares in the project area of Kuthanagere micro watershed.

\section{Bumper crop of field bean as a vegetable}

Based on the advice under NICRA project, farmers who have sown field bean in May making the best use of pre monsoon showers got good yield of the crop to the extent of 20 quintals of vegetable pod per hectare. At the market rate of Rs. 40 per $\mathrm{kg}$. The profit realized from field bean alone was Rs.80000 per hectare.

\section{Second crop after field bean}

Finger millet is the staple food crop of the farmers' and invariably the farmers transplant the crop immediately after the harvest of field bean in the month of August. Unfortunately this year, there was no soaking rains of more than $20 \mathrm{~mm}$ to undertake the transplant of finger millet in the month of August. Therefore the farmers were advised horse gram+ niger intercropping after field bean instead of finger millet as a second crop. The farmers of Ramanagara consider horse gram as poor man's meat and niger as poor man's ghee. Therefore they readily accepted to take up the second crop of horse gram intercropped with Niger in August. These two crops yielded better than finger millet since failure of rains coincided with tillering and flowering stages of finger millets. The dry spell continued in September $(-77.3 \%)$, October $(-52.4 \%)$ and November (-92.9\%) also. Thus, income from niger + horse gram intercropping was nearly Rs.20,000 per ha as against Rs.3,500 per ha from finger millet.

\section{Higher income from field bean- horse gram}

Timely advisories helped the farmers for the successful double cropping system of field bean followed by horse gram intercropped with niger.

Partial budgeting to assess the benefits of climate resilient practice revealed that the income enhancement through this climate resilient practice was Rs.1,00,500 as compared to Rs.35,500 per ha with single cropping of finger millet. The net gain from the double cropping of field bean followed by horse gram plus niger was Rs.34,500 per ha. The Overall benefit from the project was Rs.34,000 X 50 ha $=17.25$ lakhs in the project area of Kuthanagere micro watershed even during the drought year of 2016 with deficit rainfall $(-26.2 \%)$. The expected horizontal spread of this climate resilient system is over 200 ha during 2017-18. The additional employment created due to the climate resilient system was 75 man days per 
ha. Cumulative overall benefit for the project period was expected up to one crore in the next year.

Usability of forecasts provided are on an average 60 per cent while success rate of AAS issued are also around 60 per cent over the years. Advisories issued helped farmers to take up right decision on agricultural practices at the right time by reducing the labour wages, pesticides costs and also lead to achieve better yield with overall benefits from grape growers alone was Rs.2.41Crores while double cropping of field bean- horsegram gave benefit of 17.25 lakhs in project area. This clearly indicates that issuance of AAS is the better solution and failure of AAS is attributed to the failure of forecast model in providing usable forecasts.

\section{References}

Gadgil, S. (1989). Monsoon variability and its relationship with agricultural strategies. Paper presented at International symposium on climate variability and food security in developing countries. Feb 5-7, 1987, New Delhi, India pp 249-267.

GKMS, (2011), Annual report of Gramin Krishi Mausam Sewa (GKMS), Univ. Agric. Sci., Bengaluru, p. 26-30.

GKMS, (2012), Annual report of Gramin Krishi Mausam Sewa (GKMS), Univ. Agric. Sci., Bengaluru, p. 24-29.

GKMS, (2013), Annual report of Gramin Krishi Mausam Sewa (GKMS), Univ. Agric. Sci., Bengaluru, p. 27-32.

GKMS, (2014), Annual report of Gramin Krishi Mausam Sewa (GKMS), Univ. Agric. Sci., Bengaluru, p. 40-49.

GKMS, (2015), Annual report of Gramin Krishi Mausam Sewa (GKMS), Univ. Agric. Sci., Bengaluru, p. 42-49.

GKMS, (2016), Annual report of Gramin Krishi Mausam Sewa (GKMS), Univ.
Agric. Sci., Bengaluru, p. 41-48.

GKMS, (2017), Annual report of Gramin Krishi Mausam Sewa (GKMS), Univ. Agric. Sci., Bengaluru, p. 45-47

Hansen, J.W. (2002), Realizing the potential benefits of climate perdition to agriculture and challenges. Agricultural systems 74: 329-330.

Karnataka at glance, (2002-03), Directorate of economics and Statistics, Bengaluru

NICRA, (2011), Annual report of AICRPAM - NICRA (2011-2012), Univ. Agric. Sci., Bengaluru, p. 29-37.

NICRA, (2012), Annual report of AICRPAM - NICRA (2012-2013), Univ. Agric. Sci., Bengaluru, p. 49-67.

NICRA, (2013), Annual report of AICRPAM - NICRA (2013-2014), Univ. Agric. Sci., Bengaluru, p. 31-47.

NICRA, (2014), Annual report of AICRPAM - NICRA (2014-2015), Univ. Agric. Sci., Bengaluru, p. 31-40.

NICRA, (2015), Annual report of AICRPAM - NICRA (2015-2016), Univ. Agric. Sci., Bengaluru, p. 23-30

NICRA, (2016), Annual report of AICRPAM - NICRA (2016-2017), Univ. Agric. Sci., Bengaluru, p. 27-37

NICRA, (2017), Annual report of AICRPAM - NICRA (2017-2018), Univ. Agric. Sci., Bengaluru, p. 25-35

Rajegowda, M.B, (1999).Climatic conditions in different Agroclimatic zones of Karnataka, Published by UAS, Bengaluru pp -1.

Ranbirsinghrana, Rajendra Prasad and Suresh Kumar, (2005) Reliability of Medium range weather forecast in mid hill region of Himachal Pradesh. J. of Agrometeorol 7(2): 297-303

Ravindrababu, B. T, Janardhanagowda, N. A., Jagadeesha, N., K. R., Rajshekhar, Rajegowda, M. B. (2007), Application of weather based agro advisories in eastern dry zone of Karnataka. J. of Agrometeorology 9(2):259-264 
Seeley, M. W. 1994. The future of serving agriculture with weather/climate information and forecasting: some indications and observations. Agric. Forest Meteoro/.. 69:47-59.

Singh, S, V, Rathore, L. S. and Trivedi, H. K. N. 1999. Verification of medium range weather forecasts, (in) Guide for Agrometeorological advisory services pp 73-81. (Eds) National Centre for Medium Range. Weather Forecasting, Department of. Science and
Technology, -Government of India. Surendra Singh, V.U.M. Rao and Diwan Singh. 2004, Scientific support in farm decision making through weather based advisory services in Haryana. J. Agrometeorology 6 (sp.): 265-267.

Venkataraman. 2004. Climatic characterization of crop productivity and input needs for agro meteorological advisory services. J. Agrometeorology 6(11): 98-105.

\section{How to cite this article:}

Shivaramu, H.S., H.S. Padmashri, K.K. Singh, L. Nagesha, M.H. Manjunatha, H.T. Jayasshree and Munirathna, C.M. 2018. Forecasts and Agromet Advisory Evaluation. Int.J.Curr.Microbiol.App.Sci. 7(04): 2863-2871. doi: https://doi.org/10.20546/ijcmas.2018.704.326 